Arch Virol (1991) [Suppl 3]: 191-197

(C) Springer-Verlag 1991

\title{
cDNA probes for the detection of pestiviruses
}

\author{
Catherine Cruciere, L. Bakkali, Monique Gonzague and E. Plateau ${ }^{1}$ \\ ${ }^{1}$ Centre National d'Etudes Vétérinaires et Alimentaires, \\ Laboratoire Central de Recherches Vétérinaires, (C.N.E.V.A./L.C.R.V.), \\ France
}

Accepted March 20, 1991

Summary. Probes were prepared from genomic RNA of Hog Cholera Virus (HCV) after synthesis of cDNA and cloning. Six probes were selected according to their place on the viral genome determined by sequencing and comparison with BVDV sequence. These probes were hybridized with two strains of HCV (Alfort and Nord), two strains of Bovine Viral Diarrhea (BVDV) (NADL, New York) and four strains of Border Disease (BD) (Lyon 1, Lyon 2, Aveyron, IEMVT). This panel of six probes seem to be able to differentiate pestiviruses but some differences rely only on slight intensity of the hybridization.

Key words: cDNA probes, pestiviruses, diagnosis, distinction.

\section{Introduction}

Bovine viral diarrhea virus (BVDV) and border disease virus (BDV) are the cause of important diseases of large and small ruminants. These two viruses belong to the Pestivirus genus [8] and are genetically and antigenically related to hog cholera virus ( $\mathrm{HCV}$ ) of pigs.

The laboratory diagnosis of these diseases is traditionally based on virus isolation and/or serology $[5,6,7]$. Identification and differenciation between these three viruses is an important problem in pigs which can be infected by BVDV and BDV as well as by HCV.

The development of molecular biology gave a new approach to the comprehension of the biology of viruses, and new tools for the diagnosis such as cDNA probes. In this report we describe the preparation of hog cholera virus probes and their application for the detection and differentiation of pestiviruses. 


\title{
Materials and methods
}

\author{
Cells and viruses
}

The HCV strain Alfort [1] twice cloned in 96 wells plates by end point dilution and HCV strain Nord (graciously given by Dr Leforban, SPP, Ploufragen) were amplified on porcine kidney (PK) cell line 15 cultured in modified Eagle's medium (MEM) supplemented with $8 \%$ foetal calf serum (FCS). The New York BVDV strain and BDV strains Lyon 1 and Lyon 2 were graciously given by Dr Chappuis (Rhone Merieux Lyon). The BDV strain IEMVT was graciously given by Dr Lefevre (IEMVT France). Theșe strains were grown on sheep kidney (SK) cell line cultured in OPTIMEM supplemented with $10 \%$ FCS. The NADL BVDV (ATCC) strain was amplified on bovine nasal turbinate cell line (BT) cultured in MEM supplemented with $10 \%$ of basal medium supplement (BMS) (SEROMED, France). All stock cells and FCS were regularly tested for the absence of contamination by pestiviruses.

\section{Production and purification of the virus}

PK 15 cells were infected with a m.o.i. of 5 (as determined by immunofluorescence assay) of HCV (Alfort). After one hour of incubation, MEM supplemented with 5\% horse serum was added. Twenty nine hours later the infected cells were freeze-thawed three times. The viral suspension was added with $0.5 \mathrm{mg} / \mathrm{ml}$ of trypsin and incubated $10 \mathrm{~min}$ at $37^{\circ} \mathrm{C}$ before centrifugation at 3,000 g during $30 \mathrm{~min}$ and at $10,000 \mathrm{~g}$ during $1 \mathrm{~h}$. Then, the suspension was ultracentrifuged in a $45 \mathrm{Ti}$ rotor at 44,000 RPM during $3 \mathrm{~h}$. The pellet was purified with sucrose gradient $22 \%-44 \%$ ultracentrifuged at 39,000 RPM during $36 \mathrm{~h}$ in SW40.

\section{Preparation of genomic RNA}

The HCV virus pellet resuspended in TNE $(200 \mathrm{mM}$ Tris, $\mathrm{pH} 8,200 \mathrm{mM} \mathrm{NaCl}, 2 \mathrm{mM}$ EDTA) with $400 \mu \mathrm{g} / \mathrm{ml}$ of proteinase $\mathrm{K}$ was incubated $30 \mathrm{~min}$ at $37^{\circ} \mathrm{C}$. After addition of a same volume of TNE $2 \mathrm{X}$ with $2 \% \mathrm{SDS}$ it was again incubated $5 \mathrm{~min}$ at $50^{\circ} \mathrm{C}$ and $30 \mathrm{~min}$ at $25^{\circ} \mathrm{C}$, then genomic RNA was precipitated with 2.5 volumes of ethanol after phenolchloroform extraction.

\section{Synthesis of cDNA and cloning}

Approximately $10 \mu \mathrm{g}$ of RNA from purified virions and $1 \mu \mathrm{g}$ of random hexanucleotide primer in $10 \mu \mathrm{l}$ of $\mathrm{H}_{2} \mathrm{O}$ were heated to $65^{\circ} \mathrm{C}$ for $5 \mathrm{~min}$, chilled on ice and mixed with dATP, dCTP, dGTP, dTTP $1 \mathrm{mM}$ each, 15 units of RNasin or RNAase inhibitor and 100 units of AMV reverse transcriptase in buffer $\left(50 \mathrm{mM}\right.$ Tris- $\mathrm{HCl} \mathrm{pH} 8.3$ at $42^{\circ} \mathrm{C}, 8 \mathrm{mM} \mathrm{MgCl}_{2}$, $50 \mathrm{mM} \mathrm{KCl}, 1 \mathrm{mM}$ DTT) in a final volume of $100 \mu$. The mixture was incubated $30 \mathrm{~min}$ at $25^{\circ} \mathrm{C}, 30 \mathrm{~min}$ at $37^{\circ} \mathrm{C}$ and $2 \mathrm{~h}$ at $42^{\circ} \mathrm{C}$.

After phenol-chloroform extraction, the heteroduplex was treated with 17 units of RNAase $\mathrm{T}_{2}$ in $250 \mathrm{mM} \mathrm{NaCl}, 10 \mathrm{mM} \mathrm{NaCOOCH} 3 \mathrm{pH} 4.5$ during $15 \mathrm{~min}$ at $37^{\circ} \mathrm{C}$, reextracted with phenol-chloroform and filtered on sephadex G50 medium. Then the heteroduplex and the vector PBR 322 cleaved with Pst I were added with complementary homopolymer tracts. Tails of about 20 deoxycitidines were added to 2 picomoles of $3^{\prime}$ termini in a final volume of $20 \mu \mathrm{l}$ of buffer $(25 \mathrm{mM}$ Tris $\mathrm{HCl} \mathrm{pH} \mathrm{7,100} \mathrm{mM} \mathrm{potassium}$ cacodylate, $0.2 \mathrm{mM}$ DTT, $1 \mathrm{mM} \mathrm{CoCl} 2,50 \mu \mathrm{g}$ bovine serum albumim, $0.2 \mathrm{mM} \mathrm{dCTP}$ or dGTP) and 14 units of terminal transferase. The mixture was incubated $3 \mathrm{~min}$ at $37^{\circ} \mathrm{C}$, extracted with phenol-chloroform and purified on a column of sephadex G 50 medium. 
Tailed heteroduplex and vector were ligated by contact of 1 mole of heteroduplex with 2 moles of vector at a final concentration of vector of $5 \mathrm{ng} / \mu \mathrm{l}$ in buffer $(100 \mathrm{mM}$ Tris $\mathrm{HCl}$ pH 7.5, $100 \mathrm{mM} \mathrm{NaCl}, 1 \mathrm{mM}$ EDTA). The mixture was heated at $65^{\circ} \mathrm{C} 10 \mathrm{~min}$ and the annealing was performed overnight by incubation in the water bath.

The DNA recombinant was introduced in bacterial cells strain RR 1 after their treatment by calcium chloride [9].

\section{Analysis of the inserts}

After selection of transformed bacteria by tetracycline resistance and ampicillin susceptibility the plasmid DNA was obtained from minipreparations realized by alkaline lysis method [9].

After PstI digestion of the plasmid DNA, the inserts were analysed by $1 \%$ agarose electrophoresis. The inserts of a length above $500 \mathrm{pb}$ were selected.

The inserts in PBR 322 were labelled with 32P dCTP by "multiprime DNA labelling systems" (Amersham, France). Their viral origin was confirmed by hybridization with dot blot of RNA extracted from infected and non infected cells according to the method described by Maniatis (1982) for the isolation of m RNA from mammalian cells.

The respective position of these inserts was determined by reciprocal hybridization and restriction enzyme cleavage.

\section{Nucleotide sequencing}

DNA sequencing was carried out by random subcloning of sonicated DNA [4] in DNA replicative form of $\mathrm{M} 13$ phage.

The M 13 dideoxy sequencing was carried out according to Sanger technique and previously used for the sequence analysis of bovine enteritic coronavirus F 15 genome [3].

\section{Preparation of RNA from infected and non infected cells, dot-blot and hybridization}

After three freeze-thawings the cell suspension was clarified and ultracentrifugated as previously described. The pellet resuspended in 1:500 of the initial volume was treated with $2 \%$ of SDS $10 \mathrm{~min}$ at $20^{\circ} \mathrm{C}$ then RNA was extracted with phenol-chloroform and precipitated with sodium acetate $0.25 \mathrm{M}$ and 2.5 volumes of ethanol.

The RNA from infected or non infected cells was denatured by mixing with the same volume of formaldehyde and heating at $50^{\circ} \mathrm{C}$ during $15 \mathrm{~min}$. After ice chilling, a same volume of $10 \mathrm{XSSC}$ ( $20 \mathrm{X} \mathrm{SSC}$ is $3 \mathrm{M} \mathrm{NaCl}, 0.3 \mathrm{M}$ Na citrate) was added and the RNA deposited on nitrocellulose filters (Schleicher and Schüell, Ceralabo, France) wetted by $5 \mathrm{X}$ SSPE (20 X SSPE is $3 \mathrm{M} \mathrm{NaCl}, 177 \mathrm{mM} \mathrm{NaH}_{2} \mathrm{PO}_{4}, 20 \mathrm{mM}$ EDTA pH 7.4).

Pre-hybridization was performed overnight at $42^{\circ} \mathrm{C}$ in $200 \mu \mathrm{l}$ of $5 \mathrm{X}$ SSPE by $\mathrm{cm}^{2}$ of filter containing $50 \%$ formamide, $0.1 \%$ polyvinyl pyrrolidone (PVP), $0.1 \%$ ficoll, $0.1 \%$ bovine serum albumine (BSA), $0.1 \%$ SDS and $100 \mu \mathrm{g} / \mathrm{ml}$ of calf thymus DNA.

Hybridization was performed overnight at $55^{\circ} \mathrm{C}$ with $50 \mu$ of buffer by $\mathrm{cm}^{2}$ of filter with the same buffer 5 X SSPE containing $10 \mathrm{ng} / \mathrm{ml}$ of DNA probe labelled with 32P, dCTP $(110 \mathrm{TBq} / \mathrm{m} \mathrm{mol}$, Amersham) by random priming (multiprime DNA labelling system kit, Amersham) and denaturated $15 \mathrm{~min}$ at $100^{\circ} \mathrm{C}$. Washing was initially performed 3 times at room temperature during $15 \mathrm{~min}$ in $2 \mathrm{X} \mathrm{SSC}, 0.1 \% \mathrm{SDS}$ and then 2 times during $15 \mathrm{~min}$ at $52^{\circ} \mathrm{C}$ with $0.1 \% \mathrm{X} \mathrm{SSC}$ and $0.1 \%$ SDS.

For the discrimination of the pestiviruses those probes were prepared either from insert in PBR 322, either from insert in M13 DNA single strand or from insert purified from LMP agarose after electrophoresis. 


\section{Results}

Among twelve different inserts six were selected according to their location on the HCV genome determined by total or partial sequencing and comparison with the genome of the NADL strain of BVDV and Alfort strain of $\mathrm{HCV}$ as published $[2,10]$.

The place of these inserts is presented in Fig. 1.

Comparative hybridization assays were performed with the different types of probes obtained from inserts in PBR 322, M13 DNA single strand or from purified inserts. The best results (data not shown) were obtained with the purified inserts which were used in the presented results.

After dot blot hybridization with the RNA extracted from non infected cells and cells infected with various strains of pestiviruses, different intensities in the hybridizations were observed (Fig. 2) and in comparison with the controls it is possible to classify the reactions in positive, weakly positive and negative (Table 1).

The results are summarized in Table 1. One of the inserts (784) recognized all the strains, while the five other inserts reacted only with some of the eight strains of pestiviruses tested.

All the inserts used as probes recognized the two strains of $\mathrm{HCV}$ (Alfort and Nord).

The sequences of the HCV genome corresponding to the inserts were compared with the homologous regions of the BVDV genome. The highest degree of homology $(73 \%)$ was observed with the 784 insert which reacted with all the strains. A slightest homology $(66.5 \%)$ was observed with the 779 fragment which recognized strongly the two strains of HCV, the NADL strain of BVDV and more weakly two BDV strains (Aveyron and Lyon 2). The lowest homology (about 63\%) was obtained with two of the four other inserts (1610 and 1745) which did not recognize any of the two BVDV strain but only HCV and 3 strains of BDV (Aveyron, Lyon 1, Lyon 2). The degree of homology of the two last inserts is not yet determined.

\section{Discussion}

The purpose of this work was to detect and differentiate pestiviruses of different animal origin by cDNA probes. The six probes were tested against RNA extracts from undiluted and 1:10 cell extracts. When the probes reacted with undiluted dilution, a decrease of intensity of the reaction or a total extinction at the $10^{-1}$ dilution was observed.

This decrease is clear with HCV strain Nord (Fig. 2 lane $\mathrm{H}$ ) and when the BVD strain Aveyron and Lyon 2 are tested against probe 784 (Lanes D and F). The total extinction at $10^{-1}$ dilution is explained for most of the other cases when the reaction is not very important with the undiluted extracts (lanes BCEG) but not for $\mathrm{HCV}$ Alfort (Lane A). In this case, 


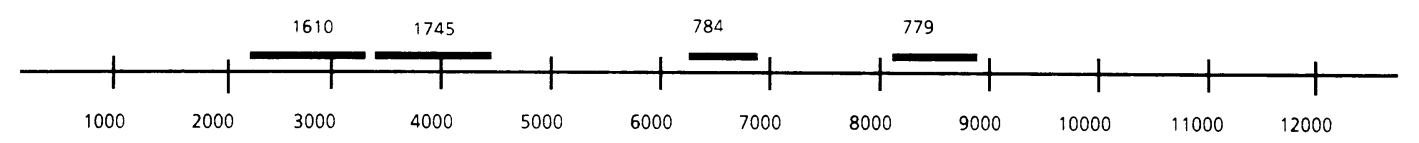

Fig. 1. Sites of the inserts $1610,1745,784,779$ on the genome of HCV. The sites of the inserts 2038 and 1331 have not been determined with precision, they are between 1745 and 784

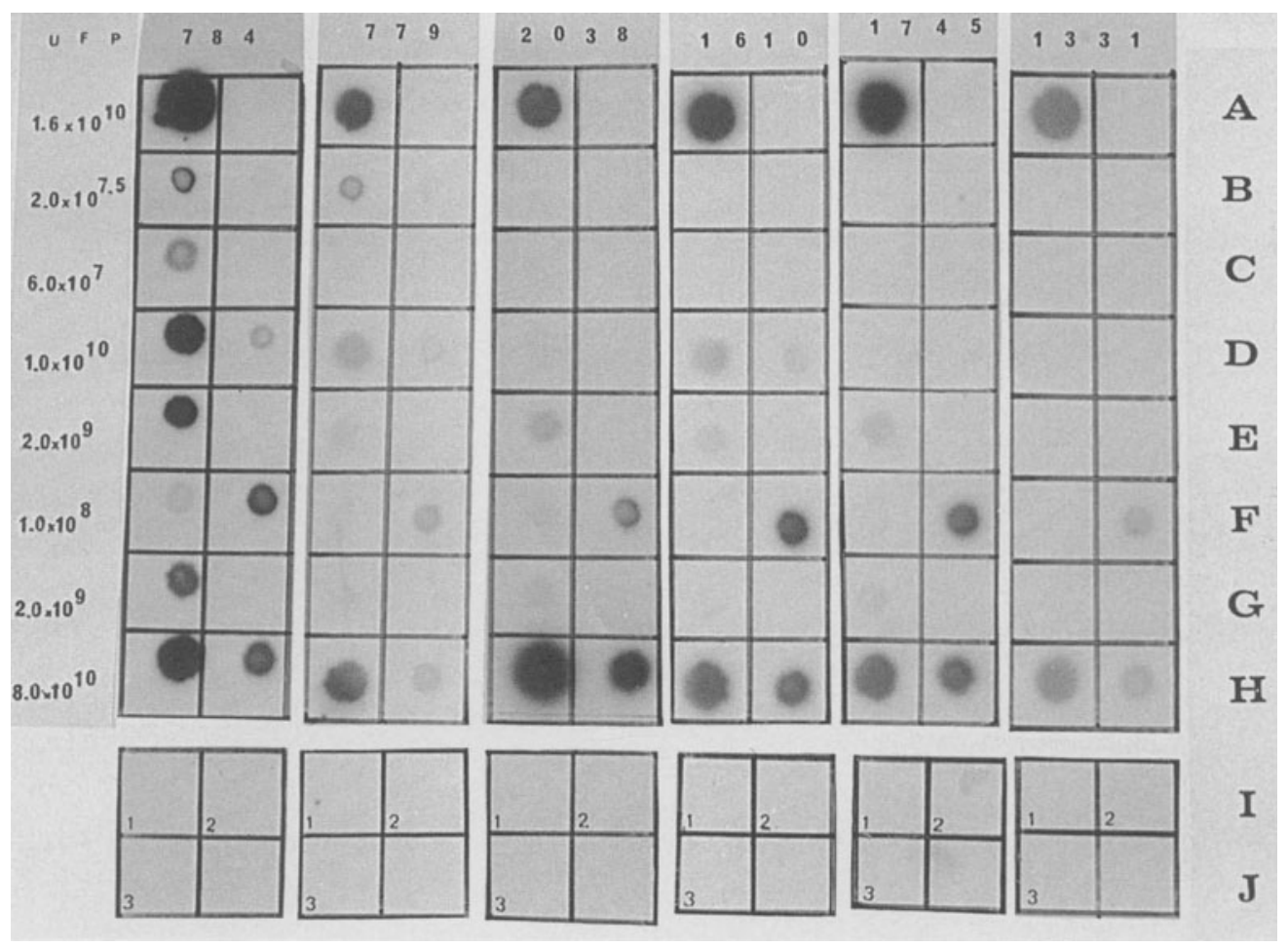

Fig. 2. Dot blot hybridization of 8 strains of pestiviruses with 6 different inserts. A: HCV strain Alfort; B: BVDV strain NADL; C: BVDV strain New York; D: BDV strain Aveyron; E: BDV strain Lyon 1; F: BDV strain Lyon 2; G: BDV strain IEMVT; H: HCV strain Nord. PFU column indicates the amount of virus deposited. Each insert was hybridized with $0.004 \mathrm{ml}$ of initial dilution of each strain (Left column) and $0.004 \mathrm{ml}$ of a $10^{-1}$ dilution of each strain (Right column). For strain F, the blots corresponding to the initial and $10^{-1}$ dilutions were unvoluntarily inverted. Lanes I and $\mathrm{J}$ : control hybridization with uninfected cells (1: PK; 2: BT; 3: SK)

despite the initial strong reaction no trace is observed at the $10^{-1}$ dilution. No explanation was given except an error in dilution manipulation.

By this panel of $6 \mathrm{cDNA}$ probes it was possible to recognize and differentiate the various strains of pestiviruses. All the probes recognized the two HCV strains, but only one probe (784) recognized the whole range of 
Table 1. Results of the dot blot hybridization expressed in positive weakly positive or negative between the HCV cDNA probes and various strains of pestiviruses

\begin{tabular}{|c|c|c|c|c|c|c|}
\hline \multirow{2}{*}{ Virus Strains } & \multicolumn{7}{|c|}{ Inserts } \\
\cline { 2 - 7 } & 784 & 779 & 2038 & 1610 & 1745 & 1331 \\
\hline $\begin{array}{c}\text { HCV } \\
\text { (Alfort) }\end{array}$ & & & & & & \\
\hline $\begin{array}{c}\text { BVDV } \\
\text { (NADL) }\end{array}$ & & & & & & \\
\hline $\begin{array}{c}\text { BVDV } \\
\text { (New York) }\end{array}$ & & & & & & \\
\hline $\begin{array}{c}\text { BDV } \\
\text { (Aveyron) }\end{array}$ & & & & & & \\
\hline $\begin{array}{c}\text { BDV } \\
\text { (Lyon 1) }\end{array}$ & & & & & & \\
\hline $\begin{array}{c}\text { BDV } \\
\text { (Lyon 2) }\end{array}$ & & & & & & \\
\hline $\begin{array}{c}\text { BDV } \\
\text { (IEMVT) }\end{array}$ & & & & & & \\
\hline $\begin{array}{c}\text { HCV } \\
\text { (Nord) }\end{array}$ & & & & & & \\
\hline $\begin{array}{c}\text { Homology } \\
\text { (HCV/BVDV) }\end{array}$ & $73.3 \%$ & $66.5 \%$ & ND & $63 \%$ & $63.7 \%$ & ND \\
\hline
\end{tabular}

$\square$ positive

$\nabla$ weakly positive

$\square$ negative

Lower line: degree of homology between the part of the HCV genome (Alfort) corresponding to the inserts and the corresponding part of the BVDV genome (NADL).

$\mathrm{ND}=$ Not determined

pestivirus strains tested and none of the probes was only specific of a single type of pestivirus. Besides, one of the BDV strain (Lyon 2) could be differentiated from the two HCV strains only by probe 779 which hybridized less with Lyon 2. In the same way the BVDV (New York) strain of pestivirus of ruminants could be differentiated from BDV (IEMVT) and BDV (Aveyron) only by a slight hybridization of probes 2038 and 1745, and probes 779 and 1610 with these two strains of BDV respectively. More probes should be necessary to avoid the difficulties due to weak hybridization and more strains of pestiviruses of different origin should also be tested to confirm these possibilities of differentiation. The highest specificity of the probes with $\mathrm{HCV}$ is not surprising as the probes were prepared from the Alfort strain of $\mathrm{HCV}$. It can be presumed that more specific BDV and BVDV probes could be prepared from homologous pestiviruses.

The sensitivity of the probes was determined only by the titer of the supernatants and the determination of the number of viral particles corresponding to the volume deposited on the filters for hybridization. The quantity of viral RNA detected was not determined as the extracts were not 
purified and contained viral and cellular RNA. In spite of this, the high titers of virus in the undiluted samples and the rapid decrease of the reaction indicates that the sensitivity is not excellent and should be improved.

The yield of such high titers is possible after adaptation of the virus and the value of the probes is still interesting for the confirmation and distinction of the pestiviruses in reference laboratories.

An important step will be the adaptation of such techniques to material directly extracted from organs or samples of infected animals, combined with the preparation of non radioactive labelled probes for a wider use in conventional laboratories.

\section{References}

1. Aynaud JM, Galicher C, Lombard J, Bibard C, Mierzejewska M (1972) Peste porcine classique: les facteurs d'identification in vitro du virus en relation avec le pouvoir pathogène. Ann Rech Vét 3: 209-235

2. Collett MS, Larson R, Gold C, Strick D, Anderson DK, Purchio AF (1988) Molecular cloning and nucleotide sequence of the pestivirus bovine viral diarrhea virus. Virology 165: 191-199

3. Crucière C, Laporte J (1988) Sequence and analysis of bovine enteritic coronavirus (F15) genome. I. Sequence of the gene coding for the nucleocapsid protein; analysis of the predicted protein. Ann Inst Pasteur/Virol 139: 123-138

4. Deininger PL (1983) Random subcloning of sonicated DNA: application to shotgun DNA sequence analysis. Anal Biochem 129: 216-223

5. Fernelius A (1964) Non cytopathogenic bovine viral diarrhea viruses detected and titrated by immunofluorescence. Can J Comp Med Vet Sci 28: 121-126

6. Fernelius AL, Antower WC, Lambert C, Mc Clurikin AW, Matthews PJ (1973a) Bovine viral diarrhea virus in swine: characteristics of virus recovered from naturally and experimentally infected swine. Can J Comp Med 37: 13-20

7. Fernelius AL, Antower WC, Malmquist WA, Lambert G, Matthews PJ (1973b) Bovine viral diarrhea in Jioine: neutralizing antibody in naturally and experimentally infected swine. Can J Comp Med 37: 96-102

8. Horzinek MC (1981) Non arthropod borne Togaviruses. Academic Press Inc, New York

9. Maniatis T, Fritsch EF, Sambrook J (1982) Molecular cloning: a laboratory manual. Cold Spring Harbour Laboratory, Cold Spring Harbour, New York

10. Meyers G, Rumenapf T, Thiel HJ (1989) Molecular cloning and nucleotide sequence of Hog cholera virus. Virology 171: 555-567

Author's address: Dr. E. Plateau, Centre National d'Etudes Vétérinaires et Alimentaires, Laboratoire Central de Recherches Vétérinaires, (C.N.E.V.A./L.C.R.V.) 22, rue Pierre Curie, 94703 Maisons-Alfort Cedex. France. 